\title{
ANALISIS FLUKTUASI KURS RUPIAH TERHADAP DOLLAR AMERIKA (1997.I - 2004.IV)
}

\author{
Anggyatika Mahda Kurnia' \\ Didit Purnomo' \\ ${ }^{1}$ Fakultas Ekonomi Universitas Muhammadiyah Surakarta
}

\begin{abstract}
The research aims at analyzing the fluctuation of Rupiah exchange rate against US dollar. Data used in the research are quarterly time series data, namely in period from 1997.I to 2004.IV. The analysis tools used in this research are multivariate linear regression by Error Correction Model (ECM). The result of this research concluded that the variables of The Rupiah exchange rate, inflation, interest rate of Bank Indonesia and import value has been stationer, only the variable of money supply on which is not stationer.

ECM analysis results in the valid model on the Rupiah exchange rate against US dollar. It is showed by the significant ECT value at $\alpha=0.05$; the regression coefficient value is 0.231835 . Based on the classical assumption test, there is not found any problem. Normality test showed that Ut distribution is normal, the model specification test by Ramsey Reset Test showed that the model used is linear. The determination coefficient showed that about $90.5813 \%$ of the Rupiah exchange rate against US dollar could be explained by the variables of the model. The result of the $t$ test analysis showed that the significant variable is the money supply $(\alpha=10 \%)$, inflation $(\alpha=1 \%)$, import value $(\alpha=1 \%)$
\end{abstract}

Keyword: exchange rate fluctuation, import, interest rate, inflation, ECM

\section{PENDAHULUAN}

Globalisasi dalam bidang ekonomi, sebagai contoh menyebabkan berkembangnya sistem perekonomian ke arah yang lebih terbuka antar Negara. Perekonomian terbuka inilah yang membawa suatu dampak ekonomis yaitu terjadinya perdagangan internasional antar negara-negara di dunia. Dengan adanya perdagangan internasional inilah maka akan dijumpai masalah baru yakni perbedaan mata uang yang digunakan oleh negara-negara yang bersangkutan. Akibat adanya perbedaan mata uang yang digunakan baik di negara yang menjadi pengimpor maupun pengekspor maka menimbulkan suatu perbedaan nilai tukar mata uang (kurs), oleh karena itu diperlukan penukaran mata uang antar Negara.

Perbedaan nilai tukar mata uang suatu negara (kurs) pada prinsipnya ditentukan oleh besarnya permintaan dan penawaran mata uang tersebut (Levi, 1996:129). Kurs merupakan salah satu harga yang lebih penting dalam perekonomian terbuka, 
mengingat pengaruhnya yang besar bagi neraca transaksi berjalan maupun bagi variabel-variabel makro ekonomi lainnya. Kurs dapat dijadikan alat untuk mengukur kondisi perekonomian suatu negara. Pertumbuhan nilai mata uang yang stabil menunjukkan bahwa negara tersebut memiliki kondisi ekonomi yang relatif baik atau stabil (Salvator, 1997: 10).

Krisis sektor keuangan (sektor finansial)

di Indonesia yang dimulai pada bulan Agustus 1997 lalu dimana krisis ini ditandai dengan terjadinya krisis nilai tukar, merupakan suatu fenomena yang dapat dijadikan contoh yang kongkrit bagaimana krisis pada sektor finansial dapat menjadi pemicu krisis ekonomi secara keseluruhan. Setelah krisis terjadi, nilai Rupiah mengalami penurunan yang sangat drastis yang menyebabkan kondisi ekonomi Indonesia melemah. Nilai tukar Rupiah secara simultan mendapat tekanan yang cukup berat karena besarnya capital out flow akibat hilangnya kepercayaan investor asing terhadap prospek perekonomian Indonesia.

Fluktuasi nilai tukar ini bagi sebagian orang dianggap sebagi salah satu penyebab terjadinya krisis ekonomi di Indonesia. Ketidakstabilan nilai tukar ini mempengaruhi arus modal atau investasi dan perdagangan internasional. Indonesia sebagai negara yang banyak mengimpor bahan baku industri mengalami dampak dari ketidakstabilan kurs ini, yang dapat dilihat dari melonjaknya biaya produksi sehingga menyebabkan harga barang-barang milik Indonesia mengalami peningkatan. Dengan melemahnya kurs Rupiah menyebabkan perekonomian Indonesia menjadi goyah dan dilanda krisis ekonomi dan kepercayaan terhadap mata uang dalam negeri.
Mengingat besarnya dampak dari fluktuasi kurs terhadap perekonomian ini maka jelas diperlukan suatu manajemen kurs yang baik sehingga kurs menjadi stabil dan fluktuasinya dapat diprediksi, sehingga pasar maupun otoritas moneter mampu melakukan langkah-langkah antisipasi meredam dampak negatif berfluktuasinya kurs terhadap perekonomian sehingga perekonomian dapat tetap berjalan dengan stabil, sehingga jika terjadi kegagalan pada manajemen kurs maka hal tersebut merupakan gangguan terhadap ketidakstabilan perekonomian yang akan berdampak luas kepada proses pembangunan ekonomi secara keseluruhan.

Penerapan sistem devisa bebas dan ditambah dengan penerapan sistem nilai tukar mengambang (free floating) di Indonesia sejak tahun 1997, menyebabkan pergerakan nilai tukar di pasar menjadi sangat rentan oleh pengaruh faktor-faktor ekonomi dengan non ekonomi. Sebagai contoh pertumbuhan nilai mata uang Rupiah terhadap dolar AS pada era sebelum krisis melanda Indonesia dan kawasan Asia lainnya masih relatif stabil. Jika dibandingkan dengan masa sebelum krisis, semenjak krisis ini terjadi lonjakan kurs dolar AS berada di antara $\mathrm{Rp}$ 6.700 - Rp 9.530 sedangkan periode 19811996 di bawah Rp 2.500 (Bank Indonesia, 2000).

Pergerakan nilai dolar AS menjadi determinan utama nilai Rupiah. Melalui mekanisme transmisi ini, inflasi serta suku bunga domestik juga turun ke tingkat terendah dalam sejarah. Sebaliknya, dengan menguatnya dolar AS belakangan ini, nilai Rupiah merosot dan berpotensi mendongkrak inflasi. Pergerakan nilai tukar yang fluktuatif ini mempengaruhi perilaku masyarakat dalam memegang uang, selain faktor-faktor 
yang lain seperti tingkat suku bunga dan inflasi. Kondisi ini didukung oleh laju inflasi yang meningkat tajam dan menurunnya kepercayaan masyarakat terhadap perbankan nasional. Permintaan uang merupakan permintaan atas saldo kas riil dari masyarakat. Pendekatan yang dapat digunakan untuk melihat perilaku permintaan uang adalah perkembangan dari uang kartal dan uang giral (Mi). Pada awal tahun 1998, MI atau sering disebut dengan uang dalam arti sempit mengalami peningkatan yang tajam sekitar $26,17 \%$ dari tahun sebelumnya, sebagai akibat naiknya nilai tukar Rupiah (Bank Indonesia, 1998).

Tingkat suku bunga yang tinggi, akan menyerap jumlah uang yang beredar di masyarakat. Jika tingkat suku bunga dinaikkan, jumlah uang yang beredar berkurang karena orang lebih senang menabung daripada memutarkan uangnya pada sektor-sektor produktif. Sebaliknya jika tingkat suku bunga terlalu rendah maka jumlah uang yang beredar di masyarakat akan bertambah karena orang lebih suka memutarkan uang pada sektor-sektor produktif daripada untuk menabung. Dalam hal ini tingkat suku bunga merupakan instrumen konvensional untuk mengendalikan inflasi (Khalwaty, 2000:144).

Inflasi menyebabkan harga barang impor lebih murah daripada barang yang di hasilkan di dalam negeri. Maka pada umumnya inflasi akan menyebabkan impor berkembang lebih cepat tetapi sebaliknya perkembangan ekspor akan bertambah lambat. Di samping itu aliran modal keluar akan lebih banyak daripada yang masuk kedalam negeri. Berbagai kecenderungan ini akan memperburuk keadaan neraca perdagangan, maka defisit neraca perdagangan yang serius mungkin berlaku. Hal ini seterusnya akan menimbulkan kemerosotan nilai mata uang (Sukirno, 2000: 308).

Untuk menjaga kestabilan nilai Rupiah bank sentral telah mengambil berbagai kebijakan dengan melihat faktor ekonomi apa yang menyebabkan nilai tukar Rupiah melemah. Kestabilan kurs Rupiah ini dicapai melalui analisis fundamental dengan melihat faktor-faktor yang mempengaruhi nilai tukar Rupiah terutama faktor-faktor ekonomi. Pada periode krisis ini bank sentral mengambil kebijakan untuk lebih mengetatkan moneter melalui kenaikan tingkat bunga SBI, sementara pemerintah menyatakan langkah stabilisasi Rupiah ditempuh dengan sinkronisasi fiskal moneter. Ini berarti BI akan terus berusaha melakukan intervensi untuk menahan fluktuasi (Bank Indonesia, 2000).

Faktor-faktor fundamental ekonomi apa yang mempengaruhi fluktuasi kurs Rupiah terhadap dolar AS dan seberapa besar efektifitas kebijakan dari analisis fundamental faktor-faktor ekonomi tersebut terhadap kurs Rupiah selama dan sesudah masa krisis akan menjadi fokus dalam penelitian ini. Dalam penelitian ini diambil beberapa faktor yang dapat mempengaruhi nilai tukar atau kurs Rupiah di antaranya adalah jumlah uang beredar, tingkat inflasi, tingkat suku bunga SBI, dan nilai impor.

\section{STUDI PUSTAKA}

\section{Teori Kurs tentang Law of One Price (Dalil Satu Harga)}

Dalil ini menyatakan bahwa dalam pasar yang kompetitif, yang bebas dari bahaya transportasi dan berbagai hambatan resmi dalam perdagangan, barang-barang identik, 
harga jual barang tersebut adalah sama untuk berbagai negara (dalam arti jika menggunakan mata uang yang sama). Dengan kata lain bahwa sama dimanapun transaksi perdagangan itu berlangsung. Dalil satu harga jika dinyatakan adalah sebagai berikut:

$\mathrm{P}_{\mathrm{Rp}}^{\mathrm{i}}=\left(\mathrm{E}_{\mathrm{Rp} / \mathrm{s}}\right) \times\left(\mathrm{P}_{\mathrm{US}}^{\mathrm{i}}\right)$

dimana $P_{R p}^{i}$ adalah harga Rupiah dari barang $i$ apabila dijual di Indonesia dan $P_{\text {Us }}^{\mathbf{i}}$ adalah harga dolar dari barang i jika dijual di Amerika. Berdasarkan persamaan (1) maka kurs Rupiah/Dolar $(\mathrm{Rp} / \$)$ adalah sebagai berikut :

$\mathrm{E}_{\mathrm{Rp} / \mathrm{S}}=\mathrm{P}_{\mathrm{Rp}}^{\mathrm{i}} / \mathrm{P}_{\mathrm{US}}^{\mathrm{i}}$

\section{Teori Kurs tentang Purchasing Power Parity}

Dalam teori ini dijelaskan bahwa perbandingan nilai satu mata uang dengan mata uang Negara lainnya ditentukan oleh tingkat harga di masing-masing negara. Teori paritas daya beli (Purchasing Power Parity) memperkirakan bahwa penurunan dalam daya beli mata uang domestik, yang ditandai oleh meningkatnya harga di dalam negeri, akan diikuti oleh depresiasi mata uang domestik dan juga sebaliknya. PPP memperkirakan nilai kurs antara Rupiah dengan dolar adalah sebagai berikut :

$E_{R p / S}=P_{R p} / P_{s}$

Dengan demikian, teori Paritas Daya Beli (PPP) menyatakan bila diukur dalam satuan mata uang yang sama maka semua tingkat harga dari seluruh negara adalah sama (Krugman, 1999: 121). Persamaan (3) disebut sebagai PPP relatif menyatakan bahwa perubahan persentase kurs antara dua mata uang pada periode tertentu sama dengan selisih antara persentase perubahan tingkattingkat harga di berbagai negara. PPP relatif menjelaskan harga-harga dan kurs mengalami perubahan sehingga nisbah daya beli dalam negeri dan luar negeri tiap negara tetap bertahan.

\section{Teori Kurs Tentang Interest Parity (Paritas Suku Bunga)}

Kondisi paritas suku bunga (interest parity) adalah suatu kondisi dimana perkiraan imbalan yang ditawarkan semua simpanan dalam berbagai mata uang asing/valuta asing sama (jika dihitung dengan menggunakan mata uang yang sama). Teori ini menyatakan perbedaan persentase antara nilai tukar forward dan untuk nilai tukar spot sama dengan perbedaan di dalam tingkat bunga untuk surat-surat berharga di kedua negara. Pada kondisi seperti ini maka pasar tidak akan mengalami kelebihan penawaran simpanan tertentu dan kelebihan permintaan simpanan untuk mata uang lainnya. Oleh karena itu dapat disimpulkan bahwa pasar valuta asing akan mencapai keseimbangan apabila kondisi paritas suku bunga (interest party) tercipta (Yuliati, 1998:100).

Perekonomian terbuka menimbulkan adanya tukar menukar barang antar negara yang di dalamnya terdapat perbandingan nilai tukar antar negara-negara yang melakukan pertukaran. Nilai tukar ini merupakan suatu harga dalam pertukaran tersebut. Dengan pertukaran inilah timbul perbandingan mata uang antar negara tersebut. Perbandingan nilai inilah yang sering disebut dengan kurs (Exchange Rate) (Nopirin, 1992:163). Dalam melakukan pertukaran inilah suatu negara 
harus memiliki satu mata uang yang menunjukkan harga dari setiap barang dan jasa yang diproduksinya. Kurs memegang peranan dalam hubungan perdagangan internasional, karena kurs dapat membandingkan harga dari setiap barang dan jasa yang dihasilkan oleh suatu negara. Nilai tukar mata uang atau kurs antara dua mata uang adalah sama dengan jumlah Rupiah yang diperlukan untuk membeli satu dolar atau dengan kata lain merupakan nilai Rupiah dalam mata uang dolar (Levi, 2001:26).

Kurs Rupiah terhadap dolar AS memainkan peranan sentral dalam perdagangan internasional, karena kurs Rupiah terhadap dolar AS memungkinkan kita untuk membandingkan harga-harga segenap barang dan jasa yang dihasilkan berbagai negara. Kurs valuta asing dapat diklarifikasikan ke dalam kurs jual dan kurs beli. Selisih dari penjualan dan pembelian merupakan pendapatan bagi pedagang valuta asing. Sedangkan bila ditinjau dari waktu yang dibutuhkan dalam penyerahan valuta asing setelah terjadi transaksi, kurs dapat diklarifikasikan dalam kurs spot dan kurs berjalan (forward exchange). Semua transaksi valuta asing yang berlangsung seketika atau langsung dimana kedua pihak sepakat untuk saling membayar secepatnya saat itu atau paling lambat dua hari setelah transaksi. Kurs yang melandasi perdagangan seketika (on the spot) disebut kurs spot (spot exchange rate) sedangkan kesepakatannya disebut transaksi spot. Beberapa kesepakatan seringkali secara khusus menetapkan suatu tanggal lebih dari dua hari, misalnya 30 hari, 90 hari, atau 180 hari, atau bahkan beberapa tahun. Kurs yang menjadi dasar bagi transaksi semacam itu disebut kurs berjangka (forward exchange).
Kurs spot dan kurs forward memang tidak selalu sama tetapi fluktuasinya selalu seiring (Krugman, 1999).

\section{Kurs dan Faktor-faktor yang Mempengaruhinya}

Bahwa perubahan reserve valuta asing (neraca pembayaran) timbul sebagai akibat kelebihan permintaan atau penawaran uang. Apabila terdapat kelebihan jumlah uang beredar maka neraca pembayaran akan defisit dan sebaliknya apabila terdapat kelebihan permintaan uang, neraca pembayaran akan surplus kelebihan jumlah uang beredar akan mengakibatkan masyarakat membelanjakan kelebihan ini, misalnya untuk impor atau membeli suratsurat berharga luar negeri sehingga terjadi aliran modal keluar, yang berarti permintaan akan valas naik sedangkan permintaan mata uang sendiri turun (Nopirin, 1997:222). Jika pemerintah menambah uang beredar akan menurunkan tingkat bunga dan merangsang untuk investasi keluar negeri sehingga terjadi aliran modal keluar pada gilirannya kurs valuta asing naik (apresiasi). Dengan menaiknya penawaran uang atau jumlah uang beredar akan menaikkan harga barang yang diukur dengan (term of money) sekaligus akan menaikkan harga valuta asing yang diukur dengan mata uang domestik (Herlambang, dkk, 2001).

Nilai tukar dibedakan menjadi dua yaitu nilai tukar nominal dan nilai tukar riil. Nilai tukar nominal menunjukkan harga relatif mata uang dari dua negara, sedangkan nilai tukar riil menunjukkan tingkat ukuran (rate) suatu barang dapat diperdagangkan antar negara. Jika nilai tukar riil tinggi berarti harga produk luar negeri relatif murah dan haga produk domestik relatif mahal. 
Persentase perubahan nilai tukar nominal sama dengan persentase perubahan nilai tukar riil ditambah perbedaan inflasi antara inflasi luar negeri dan inflasi domestik (persentase perubahan harga inflasi). Jika suatu negara luar negeri lebih tinggi inflasinya dibandingkan domestik (Indonesia) maka Rupiah akan ditukarkan dengan lebih banyak valas. Jika inflasi meningkat untuk membeli valuta asing yang sama jumlahnya harus ditukar dengan Rupiah yang makin banyak atau depresiasi Rupiah (Herlambang dkk, 2001:282). Suatu mata uang dikatakan "kuat" apabila transaksi kredit lebih besar dari transaksi outonomous debit (surplus neraca pembayaran), sebaliknya dikatakan "lemah" apabila neraca pembayaran mengalami defisit. Selanjutnya, transaksi autonomous debit dan kredit dipengaruhi oleh faktor-faktor yang berasal dari dalam negeri maupun dari luar negeri. Di antaranya faktor harga atau inflasi akan menyebabkan impor naik dan ekspor turun yang akan mengakibatkan naiknya permintaan valuta asing. Akibat selanjutnya, kurs valuta asing akan naik (depresiasi mata uang sendiri) (Nopirin, 1997:148).

Kebijakan yang dapat digunakan untuk mencapai sasaran stabilitas harga atau pertumbuhan ekonomi adalah kebijakan- kebijakan moneter dengan menggunakan instrumen moneter (suku bunga atau agregat moneter). Salah satu jalur yang digunakan adalah jalur nilai tukar, berpenảapat bahwa pengetatan moneter yang mendorong peningkatan suku bunga akan mengakibatkan apresiasi nilai tukar karena adanya pemasukan modal dari luar negeri. Hubungan antara suku bunga dengan nilai tukar dalam perekonomian terbuka di mana terdapat aliran atau arus lalu lintas modal secara bebas menjelaskan bahwa cengan adanya peningkatan suku bunga akan memperkuat nilai tukar yang disebabkan meningkatnya arus modal dari luar negeri (Arifin, 1998:8)

Di dalam pasar bebas, perubahan kurs tergantung pada bejerpa faktor yang mempengaruhi permintaan dan penawaran valuta asing. Bahwa valuta asing diperlukan guna melakukan transaksi pembayaran keluar negeri (impor). Makin tinggi tingkat pertumbuhan pendapatan (relatif terhadap negara lain) makin besar kemungkinan untuk impor yang berarti makin besar pula permintaan akan valuta asing. Kurs valuta asing cenderung meningkat dan harga mata uang sendiri turun. Demikian juga inflasi akan menyebabkan impor naik dan ekspor turun kemudian akan menyebabkan valuta asing naik. (Nopirin, 1997:148) 


\section{PENELITIAN TERDAHULU}

Tabel 1. Studi Empiris Mengenai Pengaruh Nilai Tukar Rupiah (Kurs)

\begin{tabular}{|c|c|c|c|c|}
\hline No & Nama & Judul & Variabel & Hasil Penelitian \\
\hline 1 & $\begin{array}{l}\text { Levi lqbal } \\
\text { Adios } \\
\text { (2003) }\end{array}$ & $\begin{array}{l}\text { "Analisis Fluktuasi Kurs Rupiah } \\
\text { terhadap Dollar AS". }\end{array}$ & $\begin{array}{l}\text { Dependen: } \\
\text { kurs } \\
\text { Independen } \\
\text { JUB, inflasi, } \\
\text { tingkat suku bunga } \\
\text { SBI, NPI }\end{array}$ & $\begin{array}{l}\text { Dengan menggunakan metode } \\
\text { ECM dapat dijelaskan bahwa } \\
\text { variabel JUB tidak } \\
\text { mempengaruhi kurs Rupiah, } \\
\text { sedangkan variabel inflasi, SBI } \\
\text { dan NPI mempunyai pengaruh } \\
\text { signifikan terhadap kurs Rupiah }\end{array}$ \\
\hline 2 & $\begin{array}{l}\text { Fidya } \\
\text { Iswatini } \\
(2003)\end{array}$ & $\begin{array}{l}\text { "Analisis Nilai Tukar Rupiah } \\
\text { terhadap Dolar AS da Faktor- } \\
\text { faktor yang mempengaruhi". }\end{array}$ & $\begin{array}{l}\text { Depencien: } \\
\text { kurs } \\
\text { Independen } \\
\text { Pendapatan riil, } \\
\text { Inflasi, jumlah } \\
\text { uang beredar } \\
\text { tingkat suku bunga }\end{array}$ & $\begin{array}{l}\text { Variabel jumlah uang beredar } \\
\text { dan pendapatan riil tidak } \\
\text { mempengaruhi nilai tukar } \\
\text { Rupiah (kurs), sedngkan inflasi } \\
\text { dan tingkat suku bunga } \\
\text { berpengaruh terhadap kurs. }\end{array}$ \\
\hline 3 & $\begin{array}{l}\text { Eni Setyawati } \\
\text { dan Soepatini } \\
(2004)\end{array}$ & $\begin{array}{l}\text { "Analisis Faktor-faktor yang } \\
\text { mempengaruhi Nilai Tukar } \\
\text { Fupiah terhadap Dolar AS } \\
\text { dengan Pendapatan Neraca } \\
\text { Pembayaran". }\end{array}$ & $\begin{array}{l}\text { Dependen: } \\
\text { Kurs } \\
\text { Independen } \\
\text { Suku bunga, PDB, } \\
\text { JUB, harga relatif }\end{array}$ & $\begin{array}{l}\text { Variabel tingkat suku bunga dan } \\
\text { PDB berpengaruh dan } \\
\text { signifikan dalam jangka pendek. } \\
\text { Variabel JUB dan harga relative } \\
\text { berpengaruh dan signifikan } \\
\text { dalam jangka panjang. }\end{array}$ \\
\hline 4 & $\begin{array}{l}\text { Nastain } \\
(2003)\end{array}$ & $\begin{array}{l}\text { "Analisis Pengaruh } \\
\text { Pendapatan Nasional Laju } \\
\text { Inflasi, Tingkat Suku Bunga, } \\
\text { dan Jumlah Uang Eeredar } \\
\text { terhadap Nilai Tukar Rupiah } \\
\text { terhadap Dollar AS Periode } \\
\text { 1985-2001". }\end{array}$ & $\begin{array}{l}\text { Dependen: } \\
\text { Kurs } \\
\text { Independen } \\
\text { Pendapatan } \\
\text { Nasional, laju } \\
\text { inflasi, tingkat suku } \\
\text { bunga, jumlah } \\
\text { uang beredar }\end{array}$ & $\begin{array}{l}\text { Dengan menggunakan metode } \\
\text { OLS diperoleh hasil bahwa } \\
\text { variabel pendapatan nasional } \\
\text { dan tingkat suku bunga tidak } \\
\text { berpengaruh secara signifikan } \\
\text { terhadap kurs Rupiah, } \\
\text { sedangkan variabel jumlah } \\
\text { uang beredar dan inflasi } \\
\text { berpengaruh signifikan terhadap } \\
\text { kurs Rupiah. }\end{array}$ \\
\hline 5 & $\begin{array}{l}\text { Didit } \\
\text { Purnomo dan } \\
\text { Wahyudi } \\
(2003)\end{array}$ & $\begin{array}{l}\text { "Hubungan Kausalitas Defisit } \\
\text { Neraca Transaksi Berjalan } \\
\text { dengan Kurs Di Indonesia". }\end{array}$ & $\begin{array}{l}\text { Variabel: } \\
\text { Kurs } \\
\text { Defisit neraca } \\
\text { transaksi berjalan }\end{array}$ & $\begin{array}{l}\text { Dengan menggunakan unji } \\
\text { kausalitas Granger dapat } \\
\text { disimpulkan bahwa mekanisme } \\
\text { perubahan kurs tidak } \\
\text { mempengaruhi perubahan } \\
\text { defisit neraca transaksi berjalan, } \\
\text { akan tetapi mekanisme } \\
\text { perubahan defisit neraca } \\
\text { transaksi berjalan } \\
\text { mempengaruhi perubahan kurs. }\end{array}$ \\
\hline
\end{tabular}




\section{METODOLOGI PENELITIAN}

\section{Jenis dan Sumber Data}

Jenis data yang digunakan adalah data sekunder yang terdiri dari suatu variabel terikat yaitu kurs dan empat variabel bebas yaitu jumlah uang beredar, inflasi, tingkat suku bunga SBI, dan nilai impor. Data sekunder ini bersumber pada Bank Indonesia (BI), Biro Pusat Statistik (BPS) dan daftar pustaka lainnya.

\section{Definisi Operasional Variabel}

- Kurs (Kurs)

Kurs atau nilai tukar mata uang (exchange rate) merupakan harga suatu mata uang terhadap mata uang yang lain. Dalam penelitian ini digunakan nilai tukar Rupiah terhadap dollar AS. Diukur dalam satuan Rupiah ( $\mathrm{Rp} / \$)$.

- Tingkat inflasi (INF)

Inflasi adalah kenaikan harga barangbarang kebutuhan umum yang terjadi secara terus menerus. Inflasi merupakan perubahan dari titik yang diukur dalam satuan persen.

- Jumlah Uang Beredar (JUB)

Jumlah uang beredar adalah uang dalam arti sempit yang terjadi dari uang kartal dan uang giral yang dipegang oleh masyarakat. Data jumlah uang beredar yang digunakan diukur dalam satuan milyar Rupiah.

- Tingkat Suku Bunga SBI (SBI)

Tingkat Suku Bunga SBI adalah angka rata-rata persentase suku bunga SBI yang ditetapkan oleh Bank Indonesia. Data suku bunga yang digunakan diukur dalam satuan persen.
- Nilai Impor (M)

Nilai impor adalah jumlah masukan hasil perdagangan dari luar ke dalam negeri dalam waktu tertentu. Diukur dalam satuan juta US $\$$ telah diubah menjadi satuan milyar Rupiah.

\section{Metode Analisis Data}

Alat analisis yang digunakan dalam penelitian ini adalah regresi berganda dengan metode OLS. Model yang digunakan adalah Error Correction Model (ECM), yang formulasi jangka panjang adalah sebagai berikut:

$\log$ Kurs $_{t}=\beta_{0}+\beta_{1} \log \mathrm{JUB}_{\mathrm{t}}+\beta_{2} \mathrm{INF}_{\mathrm{t}}+$

$$
\beta 3 \mathrm{SBI}_{\mathrm{t}}+\beta_{4} \log \mathrm{Mt}+\mathrm{U}_{\mathrm{t}}
$$

dimana:

$\beta_{1}, \beta_{2}, \beta_{3}, \beta_{4}=$ Koefisien Jangka Panjang

Sementara hubungan jangka pendek dinyatakan dengan persamaan sebagai berikut:

$$
\begin{aligned}
\text { D Log Kurs }_{\mathrm{t}}= & \alpha_{1} \mathrm{D} \log \mathrm{JUB}_{\mathrm{t}}+\alpha_{2} \mathrm{DINF} \mathrm{IN}_{\mathrm{t}}+ \\
& \alpha_{3} \mathrm{D} \mathrm{SBI}_{\mathrm{t}}+\alpha_{4} \mathrm{D} \log \mathrm{Mt}- \\
& \alpha_{5}\left(\log \mathrm{Kurs}_{\mathrm{t}-1}-\beta_{0}-\beta_{1} \log \right. \\
& \mathrm{JUB}_{\mathrm{t}-1}+\beta_{2} \mathrm{INF}_{\mathrm{t}-1}+\beta_{3} \mathrm{SBI}_{\mathrm{t}-1} \\
& \left.+\beta_{4} \log \mathrm{Mt}_{-1}\right)+\mathrm{U}_{\mathrm{t}}
\end{aligned}
$$

dimana:

$\alpha_{1}, \alpha_{2}, \alpha_{3}, \alpha_{4}:$ Parameter Jangka Pendek

$\alpha_{5} \quad:$ Parameter penyesuaian

\section{HASIL ANALISIS DATA}

\section{Uji Akar-akar Unit (Unit Root Test)}

Untuk mengetahui apakah data time series yang digunakan stasioner atau tidak, akan dilakukan uji akar-akar unit dan uji derajat integrasi. Apabila uji akar-akar unit (unit root test) yang dilakukan memperlihatkan 
fakta bahwa data yang diamati tidak stasioner maka dilanjutkan dengan uji derajat integrasi. Hasil dari pengujian dengan menggunakan program komputer Eviews berikut dapat dilihat pada keterangan di bawah ini.

a. Uji DF untuk Kurs Rupiah terhadap Dollar AS

Tabel 2. Hasil Uji DF Variabel Kurs Rupiah terhadap Dollar AS

\begin{tabular}{llrr}
\hline DF MODEL 1 & & & \\
\hline $\mathrm{K}=0$ & Dickey-Fuller t Statistic & 1,028510 \\
AIC $=-0,259172$ & Mac Kinnon Critical Values & $1 \%$ & $-2,6414672$ \\
(minimum) & & $5 \%$ & $-1,952066$ \\
& & $10 \%$ & $-1,610400$ \\
\hline DF MODEL 2 & & & \\
\hline K =0 & Dickey-Fuller t Statistic & & $-6,340742$ \\
AlC $=-1,073302$ & Mac Kinnon Critical Values & $1 \%$ & $-3,689194$ \\
& & $5 \%$ & $-2,971853$ \\
& & $10 \%$ & $-2,625121$ \\
\hline DF MODEL 3 & & & \\
\hline K =0 & & & $-6,331740$ \\
AIC $=-1,050770$ & Dickey-Fuller t Statistic & $1 \%$ & $-4,323979$ \\
& Mac Kinnon Critical Values & $5 \%$ & $-3,580623$ \\
& & $10 \%$ & $-3,225334$ \\
\hline
\end{tabular}

Sumber : Data sekunder yang diolah

Berdasar tabel di atas dapat dilihat uji stasioneritas dengan menggunakan uji DF menunjukkan variabel Kurs Rupiah terhadap Dollar AS Stasioner. Hal ini dapat dilihat dari semua model Akaike Information Criterion (AIC) minimum yang menunjukkan nilai Dickey-Fuller Test Statistic 1,028510 lebih besar daripada nilai Mac Kinnon Critical Values -1,952066 pada uji DF dengan signifikan 5\%, artinya variabel Kurs Rupiah terhadap Dollar AS Stasioner.

b. Uji DF untuk Jumlah Uang Beredar (JUB)

Tabel 3. Hasil Uji DF Variabel Jumlah Uang Beredar (JUB)

\begin{tabular}{llrr}
\hline DF MODEL 1 & & & \\
\hline $\mathrm{K}=0$ & Dickey-Fuller I Statistic & 3,315102 \\
AIC $=-2,361331$ & Mac Kinnon Critical Values & $1 \%$ & $-2,641672$ \\
& & $5 \%$ & $-1,952066$ \\
& & $10 \%$ & $-1,610400$ \\
\hline DF MODEL 2 & & & \\
\hline $\mathrm{K}=0$ & Dickey-Fuller t Statistic & $-, 2,280393$ \\
AIC $=-2,516335$ & Mac Kinnon Critical Values & $1 \%$ & $-3,689194$ \\
& & $5 \%$ & $-2,971353$ \\
& & $10 \%$ & $-2,625121$ \\
\hline DF MODEL 3 & & & \\
\hline K = 0 & & & $-3,153973$ \\
AIC = -2,578967 & Dickey-Fuller t Statistic & $1 \%$ & 4,284580 \\
(minimum) & Mac Kinnon Critical Values & $5 \%$ & $-3,562882$ \\
& & $10 \%$ & $-3,215267$ \\
\hline
\end{tabular}

Sumber : Data sekunder yang diolah 
Berdasar tabel di atas dapat dilihat uji stasioneritas dengan menggunakan uji DF terhadap variabel Jumlah Uang Beredar (JUB) menunjukkan bahwa variabel Jumlah Uang Beredar (JUB) tidak stasioner. Hal ini dapat dilihat dari semua model Akaike Information Criterian (AIC) minimum yang menunjukkan nilai Dickey-FullerTest Statistic -3,153973 lebih kecil dari pada nilai Mac Kinnon Critical Values $-3,562882$, artinya variabel Jumlah Uang Beredar (JUB) tidak stasioner dengan signifikan pada derajat 5\%, artinya variabel Jumlah Uang Beredar (JUB) tidak stasioner pada derajat 0,05 .

c. Uji DF untuk Inflasi

Tabel 4. Hasil Uji DF Variabel Inflasi

\begin{tabular}{llrr}
\hline DF MODEL 1 & & & \\
\hline $\mathrm{K}=0$ & Dickey-Fuller t Statistic & & $-2,757629$ \\
AIC $=6,200164$ & Mac Kinnon Critical Values & $1 \%$ & $-2,641672$ \\
& & $5 \%$ & $-1,952066$ \\
& & $10 \%$ & $-1,610400$ \\
\hline DF MODEL 2 & & & \\
\hline $\mathrm{K}=0$ & Dickey-Fuller t Statistic & & $-3,726922$ \\
AIC $=6,174580$ & Mac Kinnon Critical Values & $1 \%$ & $-3,670170$ \\
& & $5 \%$ & $-2,963972$ \\
& & $10 \%$ & $-2,621007$ \\
\hline DF MODEL 3 & & & \\
\hline K =0 & & & $-4,226687$ \\
AIC =6,131934 & Dickey-Fuller t Statistic & $1 \%$ & $-4,296729$ \\
(minimum) & Mac Kinnon Critical Values & $5 \%$ & $-3,568379$ \\
& & $10 \%$ & $-3,218382$ \\
\hline
\end{tabular}

\section{Sumber : Data sekunder yang diolah}

Dapat dilihat uji stasioneritas dengan menggunakan uji DF variabel inflasi menunjukkan bahwa variabel inflasi stasioner. Hal ini dapat dilihat dengan model uji terbaik, adalah model ketiga yang memiliki Akaike Information Criterion (AIC) minimum yang menunjukkan nilai Dickey-Fuller Test Statistic -4,226687 lebih besar daripada nilai Mac Kinnon Critical Values $-3,568379$ pada uji DF dengan signifikan pada derajat 5\%, artinya variabel inflasi stasioner pada derajat 0,05 .

d. Uji DF untuk Tingkat Suku Bunga (SBI)

Tabel 5. Hasil Uji DF Variabel Tingkat Suku Bunga (SBI)

\begin{tabular}{llrr}
\hline DF MODEL 1 & & & \\
\hline $\mathrm{K}=0$ & Dickey-Fuller t Statistic & $-1,104253$ \\
AIC $=7,253495$ & Mac Kinnon Critical Values & $1 \%$ & $-2,641672$ \\
& & $5 \%$ & $-1,952066$ \\
& & $10 \%$ & $-1,610400$ \\
\hline DF MODEL 2 & & & \\
\hline K $=0$ & Dickey-Fuller t Statistic & $-2,208065$ \\
AIC $=7,272183$ & Mac Kinnon Critical Values & $1 \%$ & $-3,670170$ \\
& & $5 \%$ & $-2,963972$ \\
& & $10 \%$ & $-2,621007$ \\
\hline DF MODEL 3 & & & \\
\hline K =0 & Dickey-Fuller t Statistic & & $-4,596248$ \\
AIC = 6,952309 & Mac Kinnon Critical Values & $1 \%$ & $-4,323979$ \\
(minimum) & & $5 \%$ & $-3,580623$ \\
& & $10 \%$ & $-3,225334$ \\
\hline
\end{tabular}

Sumber : Data sekunder yang diolah 
Dari tabel tersebut dapat dilihat uji stasioneritas dengan menggunakan uji DF terhadap variabel Tingkat Suku Bunga (SBI) menunjukkan bahwa variabel Tingkat Suku Bunga (SBI) stasioner. Hal ini dapat dilihat dari semua model Akaike Information Criterion (AIC) minimum yang menunjukkan nilai Dickey-Fuller Test Statistic -4,596248 lebih besar daripada nilai Mac Kinnon Critical Values 3,580623, artinya variabel Tingkat Suku Bunga (SBI) stasioner dengan signifikan pada derajat 5\%, artinya variabel Tingkat Suku Bunga (SBI) stasioner pada derajat 0,05 .

e. Uji DF untuk Nilai Impor

Tabel 6. Hasil Uji DF Variabel Nilai Impor

\begin{tabular}{llrr}
\hline DF MODEL 1 & & & \\
\hline $\mathrm{K}=0$ & Dickey-Fuller t Statistic & & 1,105792 \\
AIC $=-0,272561$ & Mac Kinnon Critical Values & $1 \%$ & $-2,641672$ \\
& & $5 \%$ & $-1,952066$ \\
& & $10 \%$ & $-1,610400$ \\
\hline DF MODEL 2 & & & \\
\hline $\mathrm{K}=0$ & Dickey-Fuller t Statistic & & $-3,880908$ \\
AIC $=-0,565787$ & Mac Kinnon Critical Values & $1 \%$ & $-3,670170$ \\
& & $5 \%$ & $-2,963972$ \\
& & $10 \%$ & $-2,621007$ \\
\hline DF MODEL 3 & & & \\
\hline $\mathrm{K}=0$ & & & $-4,896455$ \\
AIC $=-0,706322$ & Dickey-Fuller t Statistic & $1 \%$ & $-4,323979$ \\
(minimum) & Mac Kinnon Critical Values & $5 \%$ & $-3,580623$ \\
& & $10 \%$ & $-3,225334$ \\
\hline
\end{tabular}

Sumber : Data sekurider yang diolah

Hasil tabel di atas menunjukkan balıwa uji stasioneritas dengan menggunakan uji DF menunjukkan variabel Nilai Impor stasioner. Hal ini dapat dilihat dari semua model Akaike Information Criterion (AIC) minimum yang menunjukkan nilai Dickey-Fuller Test Statistic $-4,896455$ lebih besar daripada nilai Mac Kinnon Critical Values $-3,225334$ pada uji DF dengan signifikan pada derajat 5\%, artinya variabel Nilai Impor stasioner.

Berdasarkan uji stasioner bahwa variabel Kurs Rupiah terhadap Dolar AS, Inflasi, Tingkat Suku Bunga SBI dan Nilai Impor stasioner sedangkan variabel Jumlah Uang Beredar (JUB) tidak stasioner. Oleh karena itu tidak diperlukan uji kointegrasi sebab uji kointegrasi hanya dilakukan pada kombinasi variabel yang sama-sama tidak stasioner.

\section{Pengujian dengan ECM}

Model ECM (Error Correction Model) merupakan model ekonometrik yang dapat digunakan untuk mencari persamaan regresi keseimbangan jangka panjang dan jangka pendek. Dengan menggunakan alat bantu program komputer Eviews diperoleh hasil estimasi regresi seperti nampak pada tabel 7 .
Dari hasil analisis ECM nampak bahwa nilai ECT sebesar 0.231835 hal ini berarti nilai ECT tersebut memenuhi criteria yaitu 0 $<$ ECT $<1$. Dengan kata lain model ECM dalam penelitian ini dapat dipakai untuk menganalisis pengaruh variabel bebas yaitu jumlah uang beredar, inflasi, tingkat suku bunga SBI, nilai impor terhadap variabel tidak bebas yaitu kurs Rupiah terhadap dolar AS. 
Tabel 7. Hasil Analisis Model ECM

\begin{tabular}{lrlrr}
\hline \multicolumn{1}{c}{ Variabel } & Coefficient & Std. Error & t-Statistik & Prob. \\
\hline C & -1.833009 & 1.317550 & -1.391226 & 0.1787 \\
DLOG (JUB) & 0.485103 & 0.272563 & 1.779781 & 0.0896 \\
D (INF) & 0.011527 & 0.003943 & 2.923300 & 0.0081 \\
D (SBI) & 0.002150 & 0.004087 & 0.526149 & 0.6043 \\
DLOG (M) & 0.634137 & 0.114854 & 5.521271 & 0.0000 \\
LOG (JUB)-1)) & -0.240435 & 0.130515 & -1.842200 & 0.0796 \\
INF(-1) & -0.225283 & 0.102238 & -2.203526 & 0.0389 \\
SBI (-1) & -0.229781 & 0.100747 & -2.280779 & 0.0331 \\
LOG (M(-1)) & -0.013886 & 0.105016 & -0.132226 & 0.8961 \\
ECT & 0.231835 & 0.101780 & 2.277799 & 0.0333 \\
\hline R-squared & 0.905813 & Mean dependent var & 0.043562 \\
Adjusted R-squared & 0.865448 & S>D> dependent var & 0.208216 \\
S.E. of regression & 0.076377 & Akaika info criterion & -2.050586 \\
Sum squared resid & 0.122501 & Schwarz criterion & -1.588009 \\
Log likelihood & 41.78408 & F-statistic & 22.44016 \\
Durbin-Watson stat & 2.464037 & Prob(F-statistic) & 0.000000 \\
\hline
\end{tabular}

Sumber : Hasil data yang diolah

Dari hasil analisis regresi ECM bila ditulis dalam bentuk persamaan menjadi:

$\mathrm{D} \log$ kurs $=-1,833009(\mathrm{C})+0,485103 \mathrm{D} \log (\mathrm{JUB})^{* * *}+0,011527 \mathrm{D}(\mathrm{INF})^{*}+$

$$
\begin{aligned}
& 0,002150 \mathrm{D}(\mathrm{SBI})+0,634137 \mathrm{D} \log (\mathrm{M})^{*}-0,240435 \log (\mathrm{JUB}(-1))^{* * *}- \\
& \left.0,225283 \operatorname{INF}(-1)^{* *}-0,229781 \mathrm{SBI}(-1)^{* *}-0,013886 \log (-1)\right)+ \\
& 0,231835 \mathrm{ECT}^{* *}
\end{aligned}
$$

Keterangan

* : Signifikan $\alpha=0,01$

** : Signifikan $\alpha=0,05$

*** : Signifikan $\alpha=0,10$

Model tersebut di atas merupakan model jangka pendek, model jangka panjang harus melihat keseimbangan di mana di dalamnya tercakup serangkaian proses penyesuaian yang membawa setiap shock kepada ekuilibrium atau dengan kata lain jangka panjang suatu periode yang memungkinkan penyesuaian penuh untuk setiap perubahan yang timbul maka hubungan jangka panjang dapat ditulis sebagai berikut: 
Tabel 8. Koefisien Regresi Jangka Panjang

\begin{tabular}{cll}
\hline Variabel & \multicolumn{2}{c}{ Perhitungan } \\
\hline C & $-1,833009 / 0,231835$ & $=-7,9065240$ \\
Log JUB & $(-0,240435+0,231835) / 0,231835$ & $=0,03709535$ \\
INF & $(-0,225283+0,231835) / 0,231835$ & $=0,0282615$ \\
SBI & $(-0,229781+0,231835) / 0,231835$ & $=0,00886$ \\
Log M & $(-0,013886+0,231835) / 0,231835$ & $=0,940104$ \\
\hline
\end{tabular}

Sumber : Pertitungan Hasil Analisis

Hasil perhitungan dalam jangka panjang dapat ditulis dalam persamaan linier sebagai berikut:

$\mathrm{D} \log$ Kurs $=-7,9065240+0,03709535 \log \mathrm{JUB}^{* *}+0,0282615 \mathrm{INF}^{* *}+$ $0,00886 \mathrm{SBI}^{*}+0,940104 \log \mathrm{M}^{*}$

Keterangan:

* Signifikansi $=0,05$

** Signifikansi $=0,10$

Untuk mengetahui apakah hasil estimasi ini dapat dipercaya dilakukan pengujian asumsi klasik dan uji statistik. Uji tersebut dimaksudkan untuk memutuskan apakah taksiran-taksiran terhadap parameter sudah bermakna secara teoritis dan nyata secara statistik.

\section{Uji Kepenuhan Asumsi Klasik}

- Uji Multikolinieritas

Multikolinearitas adalah suatu kondisi dimana satu atau lebih variabel bebas berkorelasi dengan variabel bebas lainnya, atau dengan kata lain suatu variabel bebas merupakan fungsi liniear dari variabel bebas lainnya. Untuk mengetahui ada tidaknya masalah multikolinieritas maka digunakan metode Klein dan diperoleh hasil sebagai berikut yang tertera dalam tabel 9 nampak beberapa variabel D Log (JUB), D (INF), D (SBI), D Log (M), Log (M) (-1) tidak terdapat multikolinieritas sedangkan variabel Log (JUB) (-1), INF (-1), SBI ($1)$, terdapat multikolinearitas. 
Tabel 9. Hasil Uji Multikolinieritas

\begin{tabular}{lllc}
\hline \multicolumn{1}{c}{ Variabel } & $\mathbf{R i}^{\mathbf{2}}$ (1-Tol) & \multicolumn{1}{c}{$\mathbf{R}^{\mathbf{2}}$} & Multikolinearitas \\
\hline D Log (JUB) & 0,505 & 0,905813 & Tidak ada \\
D (INF) & 0,643 & 0,905813 & Tidak ada \\
D (SBI) & 0,86 & 0,905813 & Tidak ada \\
D Log (M) & 0,657 & 0,905813 & Tidak ada \\
$\log ($ JUB $)(-1)$ & 0,92 & 0,905813 & Ada \\
INF (-1) & 0,999 & 0,905813 & Ada \\
SBI (-1) & 1 & 0,905813 & Ada \\
Log (M) (-1) & 0,866 & 0,905813 & Tidak ada \\
\hline
\end{tabular}

Sumber : data sekunder yang diolah

- Uji Heteroskedastisitas

Heteroskedastisitas adalah keadaan dimana variabel pengganggu tidak mempunyai varian yang sama. Untuk mendeteksi ada tidaknya masa!ah heteroskedastisitas dilakukan pengujian dengan uji white.

Berdasarkan hasil estimasi dengan menggunakan uji white dapat disimpulkan bahwa besarnya $\chi_{\text {hitung }}^{2}=13,319429$ sedangkan $\chi_{\text {tabel }}^{2}=28,8693$ ini berarti nilai $\chi_{\text {hitung }}^{2}$ lebih kecil daripada $\chi_{\text {tabel. }}^{2}$ Jadi dapat disimpulkan bahwa dalam model tidak ditemukan masalah heteroskedastisitas.

\section{- Uji Autokorelasi}

Autokorelasi terjadi apabila nilai variabel masa lalu memiliki pengaruh terhadap nilai variabel masa kini, atau masa datang. Uji Breusch Godfrey digunakan untuk melacak keberadaan autokorelasi dalam penelitian ini.

Berdasarkan hasil estimasi dengan menggunakan uji Breusch Godfrey dapat disimpulkan bahwa besarnya Nilai $\chi_{\text {hitung }}^{2}$ dalam penelitian ini adalah $\chi^{2}=(n-p)$
$\mathrm{R}^{2}=(31-1) 0,105136=3,15408$ nilai $\chi_{\text {tabel }}^{2}(0,05: 3)=3,841$. Ini berarti nilai $\chi_{\text {hitung }}^{2}$ lebih kecil daripada $\chi_{\text {tabel maka }}^{2}$ dapat disimpulkan bahwa model tidak ditemukan masalah autokorelasi.

- Uji Normalitas

Uji normalitas yang digunakan dalam penelitian ini adalah Jarque Bera. Apabila nilai Jarque Bera lebih besar dari $\chi^{2}(\alpha, 2)$ maka distribusi $U_{t}$ adalah tidak normal. Nilai statistik Jarque Bera sebesar 1,534627 lebih kecil dibandingkan dari $\chi^{2}(0,05: 2)$ sebesar 5,99147 maka Ho : $U_{t}$ normal, dengan demikian simpulannya adalah distribusi $\mathrm{U}_{\mathrm{t}}$ normal.

- Uji Spesifikasi Model

Uji spesifikasi model pada dasarnya digunakan asumsi (CLRM) tentang linieritas model, sehingga sering disebut uji linieritas model. Pada penelitian ini digunakan uji Ramsey-Reset yang terkenal dengan sebutan uji kesalahan spesifikasi umum atau general test of specification error. 
Tabel 10. Hasil Uji Spesifikasi Model

\begin{tabular}{llll}
\hline F - statistic & 1,256039 & Probability & 0,275680 \\
\hline Log likelinood rotio & 1,888171 & Probability & 0,169408 \\
\hline
\end{tabular}

Setelah diadakan perhitungan berdasar hasil Eviews diperoleh $\mathrm{F}$ statistik sebesar 1,256039 dan $\mathrm{F}_{\text {tabel }}(0,05$; $2 ; 11)=4,84$. Jadi $F_{\text {statistik }}<F_{\text {tabel. }}$. Hal ini menunjukkan Ho diterima, maka model yang digunakan sebenarnya adalah linier.

\section{Uji Statistik}

\section{- Uji F (F test)}

Uji $F$ digunakan untuk menguji apakah model yang digunakan eksis atau tidak. Dengan menggunakan tingkat signifikansi $\alpha=0,05$ diperoleh nilai $F_{\text {tabel }}(0,05 ; 9$; $22)=2,34$. Nilai $F_{\text {hitung }}$ sebesar 23,50865 . dari sini diketahui bahwa nilai $F_{\text {hitung }}$ lebih besar dari nilai $F_{\text {tabel. }}$ Maka berada pada Ho ditolak, sehingga dapat disimpulkan bahwa persamaan dalam model cukup eksis untuk digunakan.

\section{- Koefisien determinasi $\left(R^{2}\right)$}

$\mathrm{R}^{2}$ menyatakan proporsi total variabel dependen yang dapat dijelaskan oleh variabel independen. Nilai $R^{2}$ adalah 0,905813 terletak antara 0 dan 1. Jadi koefisien determinasi menunjukkan bahwa variabel independen mempengaruhi variabel dependen sebesar $90,5813 \%$. variabel kurs dijelaskan oleh jumlah uang beredar, inflasi, tingkat suku bunga SBI, nilai impor. Sedangkan sisanya yaitu $9,4187 \%$ dijelaskan oleh variabel-variabel lain di luar model.
- Uji Validitas Pengaruh (uji t)

Uji validitas pengaruh atau t-test digunakan untuk mengetahui apakah variabel (independen i secara sendirisendiri berpengaruh secara signifikan terhadap variabel dependen.

\section{Variabel D Log (JUB )}

Dari hasil regresi diketahui bahwa besarnya nilai $t_{\text {hitung }}$ sebesar 1,779781 sedangkan nilai $t_{\text {tabel }}$ dengan $\alpha=0,10$ adalah $(0,05 ; 21)=1,721$, karena $t_{\text {hitung }} \geq$ $t_{\text {tabel}}$, maka Ho ditolak berarti variabel $D$ (JUB) berpengaruh secara signifikan terhadap kurs Rupiah terhadap dolar AS pada $\alpha=0,10$.

\section{Variabel D ( INF )}

Dari hasil regresi diketahui bahwa besarnya nilai $t_{\text {hitung }}$ sebesar 2,923300 . Sedangkan nilai $t_{\text {tabel }}$ dengan $\alpha=0,01$ adalah $t_{(0,005: 21)}=2,831$, karena $t_{\text {hitung }} \geq$ $t_{\text {tabel }}$, maka Ho ditolak berarti variabel $D$ (INF) berpengaruh secara signifikan terhadap kurs Rupiah terhadap dolar AS pada $\alpha=0,01$.

\section{Variabel D ( SBI )}

Dari hasil regresi diketahui bahwa besarnya nilai $t_{\text {hitung }}$ sebesar 0,526149 . Sedangkan nilai $t_{\text {tabel }}$ dengan $\alpha=0,10$ adalah $t_{(0,05: 21)}=1,721$, karena $t_{\text {hitung }} \leq$ $t_{\text {tabel, }}$ maka Ho diterima berarti variabel $\mathrm{D}(\mathrm{SBI})$ tidak berpengaruh secara 
signifikan terhadap kurs Rupiah terhadap dolar AS pada $\alpha=0,10$.

\section{Variabel D Log (M)}

Dari hasil regresi diketahui bahwa besarnya nilai $t_{\text {hitung }}$ sebesar 5,521271 sedangkan nilai $t_{\text {tabel }}$ dengan $\alpha=0,01$ adalah $t_{(0,005: 21)}=2,831$, karena $t_{\text {hitung }} \geq$ $t_{\text {tabel, }}$ maka Ho ditolak berarti variabel $D$ Log (M) berpengaruh secara signifikan terhadap kurs Rupiah terhadap dolar AS pada $\alpha=0,01$.

\section{Variabel Log JUB ( -1)}

Dari hasil regresi diketahui bahwa besarnya nilai $t_{\text {hitung }}$ sebesar $-1,842200$. Sedangkan nilai $t_{\text {tabel }}$ dengan $\alpha=0,10$ adalah $t_{(0,05: 21)}=1,721$, karena $t_{\text {hitung }} \leq$ $\mathrm{t}_{\text {tabel, }}$ maka Ho ditolak berarti variabel JUB (-1) berpengaruh secara signifikan terhadap kurs Rupiah terhadap dolar AS pada $\alpha=0,10$.

\section{Variabel INF (-1)}

Dari hasil regresi diketahui bahwa besarnya nilai $t_{\text {hitung }}$ sebesar $-2,203526$. Sedangkan nilai $t_{\text {tabel }}$ dengan $\boldsymbol{\alpha}=\mathbf{0 , 0 5}$ adalah $t_{(0,025: 21)}=2,080$, karena $t_{\text {hitung }} \leq$ $t_{\text {tabel, }}$ maka Ho ditolak berarti variabel INF $(-1)$ berpengaruh secara signifikan terhadap kurs Rupiah terhadap dolar AS pada $\alpha=0,05$.

\section{Variabel SBI ( -1)}

Dari hasil regresi diketahui bahwa besarnya nilai $t_{\text {hitung }}$ sebesar $-2,280779$. Sedangkan nilai $t_{\text {tabel }}$ dengan $\alpha=0,05$ adalah $t_{(0,025: 21)}=2,080$, karena $t_{\text {hitung }} \leq$ $t_{\text {tabel, }}$ maka Ho ditolak berarti variabel SBI

(-1) berpengaruh secara signifikan terhadap kurs Rupiah terhadap dolar AS pada $\alpha=0,05$.

\section{Variabel $\log M(-1)$}

Dari hasil regresi diketahui bahwa besarnya nilai $t_{\text {hitung }}$ sebesar $-0,132226$. Sedangkan nilai $t_{\text {tabel }}$ dengan $\alpha=0,10$ adalah $t_{(0,05: 21)}=1,721$, karena $t_{\text {hitung }} \geq$ $\mathrm{t}_{\text {tabel, }}$ maka Ho diterima berarti variabel Log M (-1) tidak berpengaruh secara signifikan terhadap kurs Rupiah terhadap dolar AS pada $\alpha=0,10$.

\section{Variabel ECT}

Dari hasil regresi diketahui bahwa besarnya nilai $t_{\text {hitung }}$ sebesar 2,277799. Sedangkan nilai $t_{\text {tabel }}$ dengan $\alpha=0,05$ adalah $t_{(0,025: 21)}=2,080$, karena $t_{\text {hitung }} \geq$ $\mathbf{t}_{\text {tabel, }}$ maka Ho ditolak berarti variabel ECT berpengaruh secara signifikan terhadap kurs Rupiah terhadap dolar AS pada $\alpha=0,05$.

\section{KESIMPULAN}

Berdasarkan hasil regresi model Error Correction Model ( ECM ) tentang pengaruh jumlah uang beredar, inflasi, tingkat suku bunga SBI, nilai impor terhadap kurs Rupiah terhadap dolar AS, maka ditarik kesimpulan:

1. Berdasarkan hasil pengujian, tidak ditemukan masalah dalam spesifikasi model atau dengan kata lain model yang digunakan adalah linier.

2. Berdasarkan hasil pengujian asumsi klasik untuk multikolinieritas, heteroskedastisitas, autokorelasi dan normalitas tidak terdapat penyimpangan.

3. Dari uji $F$ diperoleh $F_{\text {hitung }}$ sebesar 23,50865 dan nilai $F_{\text {tabel }}(0,05 ; 9 ; 22)=$ 2,34. Hasil uji $F$ menunjukkan bahwa 
kurs Rupiah terhadap dolar AS dapat dijelaskan oleh jumlah uang beredar, inflasi, tingkat suku bunga SBI dan nilai impor secara bersama-sama mempengaruhi kurs Rupiah terhadap dolar AS, sehingga model penelitian ini cukup eksis untuk digunakan.

4. Koefisien determinasi $\left(\mathrm{R}^{2}\right)$ menunjukkan bahwa penelitian variabel penelitian sudah tepat, karena nilai $\mathbf{R}^{2}$ yang dihasilkan hampir mencapai angka 1 . nilai koefisien determinasi sebesar 0,905813 yang menunjukkan bahwa sekitar 0,905813\% variabel kurs Rupiah dijelaskan oleh jumlah uang beredar, inflasi, tingkat suku bunga SBI dan nilai impor. Sedangkan sisanya yaitu $9,4187 \%$ dijelaskan oleh variabel-variabel di luar model.

5. Hasil analisis dengan uji t diketahui bahwa variabel yang mempunyai pengaruh yang signifikan adalah jumlah uang beredar pada $\alpha=0,10$, inflasi pada $\alpha=0,01$, nilai impor pada $\alpha=0,01$ terhadap kurs Rupiah terhadap dolar AS. Sedangkan variabel yang tidak mempunyai pengaruh signifikan adalah tingkat suku bunga SBI terhadap kurs Rupiah terhadap dolar AS.

6. Variabel ECT signifikan pada tingkat signifikan $\alpha=0,05$ dengan nilai koefisien regresi sebesar 0,231835 .

\section{DAFTAR PUSTAKA}

Anonim, berbagai edisi, Statistik EkonomiKeuangan Indonesia, Jakarta: Bank Indonesia

, berbagai edisi, Laporan Tahunan, Jakarta: Bank Indonesia
Adios, Levi Iqbal, 2003. Analisis Fluktuasi Kurs Rupiah terhadap Dollar AS, Skripsi tidak diterbitkan. Surakarta: Universitas Sebelas Maret.

Arifin, Samsjul. 1998. Buletin Ekonomi Moneter dan Perbankan, Vol. 1 No. 3, Desember

Boediono, 1990. Ekonomi Internasional: Seri Sinopsis Pengantar Ilmu Ekonomi, Edisi Pertama, Yogyakarta: BPFE UGM.

\section{, 2000. Ekonomi Mikro, Yogyakarta: BPFE UGM.}

Gujarati, Damodar, 1995. Ekonometrika Dasar. Jakarta: Erlangga. , 1997. Ekonometrika Dasar. Jakarta: Erlangga. , 2002. Ekonometrika Dasar. Jakarta: Erlangga.

Herlambang, Sugiarto, Brastoro Said Kelana, 2001. Ekonomi Makro: Teori Analisis dan Kebijakan. Jakarta: Gramedia Pustaka Utama

Iswatini, Fidya. 2003. Analisis Nilai Tukar Rupiah terhadap Dollar AS dan Faktorfaktor yang Mempengaruhinya. Skripsi tidak diterbitkan. Surakarta: Universitas Muhammadiyah Surakarta

Khalwaty, Tajul, 2000. Inflasi dan Solusinya. Jakarta: PT. Gramedia Pustaka Utama.

Krugman, Paul R and Maurice Obstfeld, 1999. Ekonomi Internasional: Teori dan Kebijakan Edisi Kedua Alih Bahasa oleh Haris Munandar dan Faisal Basri, Jakarta: Raja Grafindo Persada. 
Kuncoro, Mudrajad, 1996. Manajemen Keuangan Internasional, Edisi Pertama, Yogyakarta: BPFE UGM.

Levi, Maurice D. 1996. Keuangan Internasional. Yogyakarta: Andi Offset . 2001. Keuangan Internasional. Yogyakarta: Andi Offset

Nastain. 2003. Analisis Pengaruh Pendapatan Nasional, Laju Inflasi, Tingkat Suku Bunga dan Jumlah Uang Beredar Terhadap Nilai Tukar Rupiah terhadap Dollar AS Periode 1985-2001. Skripsi tidak diterbitkan. Surakarta: UMS.

Nopirin, 1992. Ekonomi Moneter. Buku II. Yogyakarta: BPFE UGM. , 1997. Ekonomi Moneter. Buku l. Yogyakarta: BPFE UGM.

Purnomo, Didit dan Wahyudi. 20003. Hubungan Kausalitas Defisit Neraca Transaksi Berjalan dengan Kurs di Indonesia. JEP. Vol. 4 No. 1, Juni.
Santoso, Ruddy Tri. 1994. Pembiayaan Transaksi Luar Negeri. Yogyakarta: Andi Offset

Setyowati, Eni dan Soepatini. 2004. Analisis Faktor-faktor yang Mempengaruhi Nilai Tukar Rupiah terhadap Dollar AS dengan Pendekatan Neraca Pembayaran (Pendekatan Engle Granger Error Correction Model). JEP Vol. 5, No. 2. Desember.

Sukimo, Sadono, 2000. Makro Ekonomi Modern Perkembangan Pemikiran dari Klasik hingga Keynesian Baru, Jakarta: PT. Raja Grafindo Persada.

Susilo. Y. Sri, Sigit Triandaru, A. Totok Budi Santoso, 2000. Bank dan Lembaga Keuangan lain, Jakarta: Salemba Empat.

Utomo, Yuni Pribadi. 2005. Penurunan Model Estimasi Jangka Pendek ECM. Surakarta (makalah tidak diterbitkan).

Yuliati, Sri Handaru dan Handoyo Prasetyo. 1998. Dasar-dasar Manajemen Keuangan Internasional. Yogyakarta: Andi Offset. 